\title{
ИСКУСТВА ЛГБТ ОСОБА У МЕЪУЉУДСКИМ ОДНОСИМА И СФЕРИ РАДА У СРБИЈИ
}

\begin{abstract}
Ancтракт: На основу резултата истраживања добијених фокус-групним интервјуом настојала су се описати искуства ЛГБТ особа у међуљудским односима и сфери рада. Истраживање је спроведено на пригодном узорку који се састојао од 6 учесника истраживања, при чему су три учесника мушког и три учеснице женског пола који су припадници ЛГБТ популације. У раду се на основу представљених искустава ЛГБТ особа у међуљудским односима, као и у сфери рада потврђују резултати бројних истраживања на ову тему и указује да је и даље присутан виши степен толеранције према испољавању женске него мушке хомосексуалности. Резултати истраживања показују да се гејеви сусрећу са бројнијим проблемима у односу на лезбејке, како у међуљудским односима, тако и у сфери рада. Генерално сви учесници истраживања су наишли на неприхватање, критику и осуду од стране родитеља по откривању своје сексуалности. Међутим, након одређеног времена чланови породице су у мањој или већој мери то прихватили, при чему је ипак дошло до промене њихових међусобних односа, које карактеришу ређи контакти са члановима породице, као и мањи степен међусобног поверења и поверавања. Са друге стране, гејеви су се сусрели и са увредама и избегавањем од стране својих дугогодишњих пријатеља по откривању своје сексуалне оријентације и потешкоћама приликом склапања нових пријатељстава, док у случају лезбејки сексуалност није утицала на њихове односе са пријатељима и познаницима. Када је реч о искуствима ЛГБТ особа у сфери рада, резултати показују да мушки учесници истраживања теже проналазе запослење, али и да се на самом радном месту суочавају са разним типовима негативне дискриминације, док у случају женских учесница истраживања негативна дискриминација није присутна због њихове сексуалности, чак је у појединим случајевима присутна и позитивна дискриминација.
\end{abstract}

Кључне речи: хомосексуалност, искуства ЛГБТ особа, социјални контакти, сфера рада

\footnotetext{
${ }^{1}$ mariocekic@hotmail.com
} 


\section{Увод}

Питање права и положаја ЛГБТ ${ }^{2}$ заједнице, како у свету, тако и на нашим просторима, новијег је датума. Борба за права особа хомосексуалне оријентације у Европи јавља се тек средином 19. века ${ }^{3}$, иако истополни односи нису искључиво феномен савременог друштва знајући да је ова врста односа уочена још у старој Грчкој, али му се у последњих 30-ак година придаје посебна пажња и у значајној је мери у фокусу јавности (Хулић et al. 2015: 221).

У старој Грчкој хетеросексуално понашање је било доминантно, али је истовремено постојала толеранција и ка хомосексуалним односима који су схватани као један проширен начин постизања сексуалног ужитка. Наиме, љубав мушкарца према жени је схватана као нижи облик задовољавања инстинката, док је љубав мушкарца са мушкарцем потпуна - духовна и телесна (Стојановић et al. 2016: 34, 35). Сматра се да је до трансформације ставова према особама хомосексуалне оријентације дошло у периоду тзв. мрачног доба. Током средњег века под утицајем цркве хомосексуалност је почела да се сматра грехом. Снажан утицај хришћанске цркве која је одувек заступала нетрпељиве ставове у великој мери је допринео осуди и прогону особа са хомосексуалном оријентацијом од стране друштва (Стојановић et al. 2016: 35). Негде крајем 12. века долази до учвршћивања непријатељског става према истополним односима који временом усвајају све европске религије и световне институције карактеришући хомосексуалност као нешто што није природно, што је заправо довело до јачања стигме и негативног става према овој популацији. Такође и са самог становишта медицине, а посебно психијатрије на хомосексуалност се гледало као на патолошку категорију све до краја 19. века (Дуишин и Баришић, 2014: 106).

Хомосексуалност је била присутна и у средњовековној Србији чему у прилог сведочи постојање закона којим се осуђују истополни односи. Наиме, у средњовековном српском друштву постојала је смртна казна за хомосексуалце, при чему је сам сексуални чин између припадника истог пола означен као гадан (Бојанин, 2014: 32-33). Хомосексуални чин сматран је противприродним грехом и као такав је представљао незаконито дело (Бојанин, 2014: 36).

У 20. веку се јављају модерне дебате на тему хомосексуалности које доводе до промене научних ставова доминантних готово све до краја 19. века. Зачетником ове револуције се често сматра Сигмунд Фројд (Freud) који је у свом раду Drei Abhandlungen zur die Sexualtheorie (O сексуалној теорији) негирао став о хомосексуалности као патолошкој појави, истичући да је она „заос-

\footnotetext{
2 ЛГБТ се дефинише као „[...] свеобухватни појам који се користи како би се означиле лезбејке, геј мушкарци, бисексуалне и трансродне особе. Појам означава хетерогену скупину која се обично именује насловом ЛГБТ у друштвеном и политичком активизму” (Чаушевић et al. 2013: 51).

${ }^{3}$ Средином 19. века су Карл Хенрик Улрикс (Ulrichs) и Карл Марија Кертбењи (Kertbeny) заговарали декриминализацију хомосексуалности, будући да је била третирана као казнено дело за које су биле прописане смртне казне (Кондор-Лангер, 2015: 284).
} 
тајање у психосексуалном развоју” (Стојановић et al. 2016: 30). Управо су прве научне теорије о хомосексуалности настале у оквиру психологије, али и биологије $\mathrm{e}^{4}$, док се касније у оквиру социолошке парадигме јавља изузетно значајна социоконструктивистичка перспектива и теорија етикетирања, која пружа ново светло на ову проблематику.

Из социоконструктивистичке перспективе сексуални идентитет је друштвени конструкт, а „шта ће ући у његову дефиницију зависи од нормативног обрасца датог друштва, односно од ставова, реакција и понашања јавног мњења према особама хомосексуалне оријентације” (Николајевић, 2012: 41). Конструкција хомосексуалности и самим тим ставови према истој зависе од социокултурних услова, при чему „идентитети нису унапред дати већ су продукти комплексних социјалних односа" (Weeks, 1990: 50). Џон Ганон (Gagnon) и Вилијем Сајмон (Simon) су развијајући теорију „сценарија” (script), истицали да сексуалност није урођена особина, већ производ друштвеног етикетирања. Наиме, они истичу да се сексуалност социјално учи. Сваки појединац током одрастања је учен од стране друштва која се осећања и жеље рачунају као сексуалне и који су „сценарији” сексуалног понашања одговарајући и прихватљиви (Сајдмен, 2009: 68).

Управо се у поменутим примерима може видети како се кроз историју, у различитим социокултурним околностима „иста ствар” - хомосексуалност, на различит начин конструише и посматра. Док је у старој Грчкој на одређени начин хомосексуалност била прихваћена, у средњем веку под утицајем црквене догме, истополни односи су сматрани грехом и кажњавани смрћу. Другим речима, ставови према хомосексуалном понашању су културално специфични и умногоме су се мењали у зависности од културе и током различитих историјских периода (Викс, 2009: 18).

Са друге стране, теорија етикетирања нам указује да је неки чин и/или појединац девијантан у зависности од етикете коју му други „прилепе”. Девијантност, као таква није нешто што је суштински припадајуће, него „друштвене групе стварају девијантност стварајући правила чије кршење сачињава девијантност, примењујући та правила на одређене људе и етикетирајући их као аутсајдере“ (Бекер, 1998: 80). Наравно, доминантне друштвене групе у чијим рукама је моћ су те које стварају правила и намећу их другим групама са мало или нимало моћи, без обзира на њихов пристанак и вољу. Појединац који је етикетиран као девијантан се у свакодневном животу само због „прилепљене” етикете може сусрести са бројним проблемима, као што је дисфункционалност у социјалним контактима, отежано проналажење посла, друштвена изолација и слично.

Данас постоје бројна истраживања о положају ЛГБТ особа, али се она претежно односе на ставове и социјалну дистанцу према овој популацији, док

\footnotetext{
${ }^{4}$ Биолошке теорије на хомосексуалност гледају као на облик атавизма (силазак низ еволуциону лествицу), преко разних варијанти хормоналних теорија (поремећена функција хипоталамуса или полних жлезда узрокује вишак женских хормона) до претпоставки о генетском поремећају (Николајевић, 2012: 41).
} 
су ретки радови који се баве темом самог положаја и проблема хомосексуалних особа у нашој земљи из перспективе самих гејева и лезбејки (Вуковић, 2010; Николајевић, 2012; Геј Стрејт алијанса, 2014; Дуишин и Баришић, 2014; Стојановић, 2016). Како би се разумео положај ЛГБТ популације у Србији и потешкоће са којима се суочавају, неопходно је добити и информације „из прве руке”, што се настојало урадити овим истраживањем. Резултати истраживања могу се користити у циљу даљег расветљавања искустава особа хомосексуалне оријентације у нашој земљи.

\section{Преглед ранијих истраживања}

Једно од првих истраживања које је за циљ имало испитивање реакције родитеља на признање њиховог детета да је хомосексуалне оријентације спровео је крајем прошлог века Бен-Ари (Ben-Ari, 1989). Резултати су показали да је најчешћа реакција родитеља била шок, узнемиреност и порицање, а највећи проблем за родитеље је била немогућност продужења потомства. Са друге стране, 40\% испитаника истиче да је након 6 месеци од када су признали своју сексуалност родитељима дошло до побољшања односа.

Важност истраживања породичних односа након откривања сексуалне оријентације ЛГБТ особа члановима своје породице, огледа се у томе што ЛГБТ особе које имају подршку породице имају развијеније самопоуздање и самопоштовање, те су интегрисаније у друштво. Насупрот томе, страх од изражавања сопственог идентитета унутар породице доводи не само до дисфункционалних односа унутар породице, већ и до немогућности остваривања квалитетних веза и односа у свим сегментима живота. Неретко је случај да особе хомосексуалне оријентације не говоре јавно о својој сексуалности, из страха да то може довести до аутовања које има бројне последице, као што су губитак посла, мобинг, друштвена изолација, осећање стида, па чак неретко и суицида код те особе (Стојановић et al. 2016: 26).

На нашим просторима постоје бројни радови који се баве хомосексуалношћу што указује на актуелност ове теме. Истраживање под називом Стигматизација младих ЛГБТ особа од стране државних институција (2016) које је спровела А. Стојановић са сарадницима показује да највећи проценат хомосексуалних особа доживљава негативне реакције због своје сексуалности у ужој $(58,3 \%)$ и широј породици $(73,9 \%)$, првенствено од стране родитеља $(58 \%)$, затим се велики проценат негативних реакција јавља и на послу где особа ради $(52,6 \%)$, као и у школи или на факултету који похађа (66,7\%).Са друге стране, главни разлози испитаника за „боравак у орману” скривајући своју сексуалност је страх од одбацивања од стране породице и пријатеља $(31,4 \%)$, као и страх од губитка посла.

Бројна истраживања указују да ЛГБТ особе претежно због своје сексуалне оријентације имају потешкоћа у друштвеним односима, јер постоји социјална дистанца према њима. У истраживању хомофобије у Србији (Вуковић et al. 
2010) установљено је да постоји врло висок ниво социјалне дистанце према особама хомосексуалних склоности, будући да већина испитаника (64\%) не жели да се дружи са ЛГБТ особама, док готово половина испитаника не би желела на послу да има колегу (47\%) или шефа хомосексуалне оријентације (56\%). Једино постоји ниска социјална дистанца када је у питању прихватање особа хомосексуалних склоности за сународнике и суграђане.

У Извештају о стағу људских права у ЛГБТ заједници у 2008. години указује се на готово идентичне резултате, будући да се у поменутом извештају истиче да су ЛГБТ особе прихватљиве само као суграђани или сународници, док су неприхватљиве као сарадници или надређени на послу, као руководиоци, као пријатељи или сродници (Николајевић, 2012: 43 према Геј стрејт алијанса и ЦеСИД, 2009). У Годишьем извештају о стағу људских права у ЛГБТ заједниии за 2014. годину истиче се да је ЛГБТ популација и даље једна од друштвених група које су у највећој мери изложене мржњи и нетолеранцији, али је ситуација боља за ЛГБТ особе него претходних година, јер није дошло до пораста случајева насиља и дискриминације, иако су ови случајеви још увек присутни. Степени толеранције и прихватања различитости су још увек далеко од задовољавајућих, будући да је још увек најзаступљенија предрасуда да су ЛГБТ особе болесне, што сматра око 50\% грађана, како се наводи у извештају (Геј стрејт алијанса, 2014). У поменутом извештају из 2014. године наводи се и случај дискриминације на радном месту искључиво због другачије сексуалне оријентације. Наиме, 2014. године Д. К. из Зрењанина се сусрео са дискриминацијом због сазнања његових колега и шефа да је хомосексуалне оријентације. Након овог сазнања колеге су почеле редовно да га понижавају, исмејавају и вређају упућујући му погрдне називе, а његови претпостављени на послу су стално почели да га пребацују са једног на друго радно место, а свако наредно место је било или напорније или са мањом платом (Геј стрејт алијанса, 2014: 94). Управо наведени случајеви пружају потврду оправданости страха ЛГБТ особа да „изађу из ормана”.

Важно је истаћи да бројни истраживачки налази указују и на већу толерантност према испољавању женске него мушке хомосексуалности. У једном од таквих истраживања које је било усмерено на истраживање ставова према мушкој и женској сексуалности (Николајевић, 2012) установљено је да већини мушкараца (60,5\%) еротска сцена између две жене није одвратна, док је еротска сцена између два мушкарца увек одвратна већини мушкараца $(65,1 \%)$. Са друге стране, 48,8\% мушкараца ужива да гледа еротске сцене између две лезбејке, док 83,7\% мушкараца не ужива у истим таквим сценама када су актери гејеви.

\section{Методолошки оквир истраживања}

Предмет истраживања су искуства ЛГБТ особа. Циљ истраживања је опис искуства ЛГБТ особа у међуљудским односима и сфери рада. Под искуством у међуљудским односима у овом истраживању подразумевају се, са једне стране 
искуства унутар породице, али и искуства у социјалним контактима, односно, искуства учесника истраживања приликом склапања нових пријатељстава и односи са блиским пријатељима са друге стране. Да би се постигао циљ истраживања, постављени су следећи задаци:

- Испитати искуство особа хомосексуалне оријентације унутар породице - да ли су учесници истраживања по откривању своје сексуалне оријентације наишли на подршку, охрабрење или пак осуду, критику и одбацивање од стране чланова породице.

- Испитати искуство особа хомосексуалне оријентације у социјалним контактима - да ли су по откривању своје сексуалности учесници истраживања наишли на подршку или избегавање од стране блиских пријатеља, али и да ли због своје сексуалне оријентације имају потешкоћа приликом склапања нових пријатељстава и да ли наилазе на избегавање, погрдне коментаре, исмејавање и слично.

- Испитати искуство особа хомосексуалне оријентације приликом запослења и искуство у међуљудским односима на радном месту - да ли су учесници истраживања због своје сексуалне оријентације имали потешкоћа приликом запошљавања, али и какав је однос послодавца и колега на радном месту био према њима уколико су знали њихову сексуалну оријентацију.

- Испитати да ли постоје разлике у искуствима особа хомосексуалне оријентације у свим наведеним областима (унутар породице, социјалним контактима, у сфери рада) у зависности од социодемографских карактеристика (пол, године старости, место становања - село/град).

Истраживање је спроведено током фебруара месеца 2020. године на пригодном узорку који се састојао од 6 учесника истраживања са територије Републике Србије, при чему су три учесника мушког и три учеснице женског пола који су припадници ЛГБТ популације. Четири учесника истраживања су из градске средине (Београд, Ниш, Суботица), док су два учесника из сеоске средине. Просечна старост учесника истраживања је 27 година, при чему најмлађи учесник истраживања има 21, а најстарији 34 године.

Подаци у овом истраживању су прикупљени на основу фокус-групног интервјуа, а помоћу аудио записа интервјуа су сачињени транскрипти који су анализирани у раду. Ради заштите и анонимности учесника истраживања, током анализе користиће се иницијали како се не би открио њихов идентитет.

Теме које су обухваћене водичем за фокус групе и које су у складу са задацима истраживања су следеће:

- Реакције унутар породице на хомосексуалну оријентацију учесника истраживања (подршка, охрабрење, осуда, критика, одбацивање).

- Искуства учесника истраживања у социјалним контактима (евентуалне потешкоће приликом склапања нових пријатељства, погрдни коментари, исмевање, избегавање, подржавање, однос са блиским пријатељима). 
- Искуства учесника истраживања приликом запослења и међуљудски односи на радном месту (потешкоће припадника ЛГБТ популације приликом запошљавања, третман и однос послодаваца према особама хомосексуалне оријентације, однос колега на радном месту према особама хомосексуалне оријентације).

\section{Приказ резултата истраживања и дискусија}

\section{Реакиије унутар породице на хомосексуалну оријентацију учесника истраживана}

Разговор са учесницима истраживања у оквиру теме која се односила на реакцију породица на њихову хомосексуалну оријентацију указује да је већина учесника истраживања признала члановима своје породице своју сексуалну оријентацију, односно њих четворо, док двоје учесника још увек то скрива, јер страхује од саме реакције, као и евентуалног одбацивања од стране породице.

Сви испитаници који су саопштили породици своју сексуалну оријентацију истичу да је то признање допринело поремећају односа унутар саме породице, будући да су их, најпре родитељи оштро критиковали, осуђивали и кажњавали. Наиме, прва реакција родитеља по сазнању да су њихова деца хомосексуалне оријентације подразумевала је осуду и неприхватање, како П. М. истиче: „Искрено дуго сам се размишљао на који начин да саопштим родитељима да сам геј, јер нисам могао више да држим то у себи. Реакција је мање више била какву сам и очекивао, јер су моји родитељи старомодни и њихов главни сан је био да дочекају моју женидбу и унуке. Када сам им рекао да сам геј, моја мајка је почела да плаче и изашла је из собе, док је отац био изузетно љут. Сећам се да је викао и да ме је псовао, чак ми је рекао да треба да се лечим. Нико ме у породици у том тренутку није разумео, нити подржао”. Са друге стране, и код женских учесника истраживања прва реакција родитеља је била мање више слична, како С. Т. наводи: „Када сам рекла својим укућанима да сам хомосексуалне оријентације нисам наишла на подршку. Осуђивали су ме и критиковали, и стално су ме окривљивали наглашавајући како су ми све у животу пружили, а ја им овако враћам”.

Иако се често истиче дихотомија града као модерног и села као традиционалног, резултати истраживања показују да традиционалност и патријархално схватање по питању хомосексуалности доминирају и у граду. Наиме, учесници истраживања из града су наишли на готово идентичну реакцију од стране породице као и учесници истраживања са села, након откривања своје сексуалности.

Бројна истраживања указују да након одређеног времена од када су ЛГБТ особе признале своју сексуалност родитељима, долази до побољшања односа у односу на прву реакцију родитеља која је пропраћена негодовањем, неподржавањем, критиковањем и слично ${ }^{5}$. У складу са тим наредно питање се односило

\footnotetext{
${ }^{5}$ У истраживању које је спровео Бен-Ари 40\% испитаника истиче да је након 6 месеци од када су признали своју сексуалност родитељима дошло до побољшања односа (опширније у одељку: Преглед
} 
на тренутне односе учесника истраживања са њиховим члановима породице, када је прошло одређено време од њиховог признања да су хомосексуалне оријентације. Одговори показују да су њихове породице у мањој или већој мери то прихватиле, али да су односи унутар саме породице у одређеној мери захладнели и промењени, односно, нису као што су били пре признања учесника истраживања да су хомосексуалне оријентације. Ова одређена промена у односима и дистанца се огледају у смањеном контакту (разговор уживо, разговор путем телефона, размена порука) са члановима породице који нису учестали као раније, затим учесници истраживања знатно мање времена проводе са породицом него раније, али је и присутан мањи степен поверења, односно сви учесници истраживања много ређе одлучују да се о својим тренутним проблемима поверавају члановима своје породице, него што је то раније био случај.

Сви учесници истраживања су по откривању своје сексуалности члановима породице наишли на неразумевање, неприхватање, осуду и критику. Наредни заједнички моменат за све случајеве је у томе што је након одређеног временског периода од откривања своје сексуалности дошло до побољшања односа унутар породице, с тим што су ти односи мање присни него раније.

\section{Испитивање искуства учесника истраживања}

\section{у соиијалним контактима}

У наставку су питања била усмерена ка испитивању утицаја хомосексуалне оријентације на социјалне контакте из угла и личног искуства ЛГБТ особа. На питање Да ли имате потешкоћа приликом склапања нових пријатељстава због ваше сексуалне оријентащије?, сви мушки учесници истраживања су са једне стране одговорили да немају потешкоћа приликом упознавања нових људи, уколико они не знају њихову сексуалну оријентацију. Међутим, проблеми настају уколико људи са којима се упознају знају да су хомосексуалне оријентације сходно чему често одбијају да се уопште упознају и/или им се подсмевају, док у појединим случајевима то иде и до физичког напада. Један учесник истраживања дели са нама своје искуство: „Прошле године када сам срео два пријатеља из средње школе, пришао сам и поздравио сам се са њима. У њиховом друштву су била још два, мени непозната момка, којима сам пружио руку како бих се упознао, међутим, један од тих момака ми је стегао руку и ударио ме је у стомак, а други ме је вређао искључиво на рачун моје сексуалности. То је била једина ситуација када сам био физички нападнут приликом упознавања нових људи”. Са друге стране, све учеснице истраживања наводе да нису наишле на потешкоће и непријатне ситуације приликом склапања нових пријатељстава због своје сексуалности.

Приликом разматрања да ли су се учесници истраживања сусрели са увредама и избегавањем од стране својих старих, дугогодишњих пријатеља након што су им признали своју сексуалну оријентацију, показало се да су гејеви наишли на ове проблеме, док лезбејке нису уопште или врло ретко. Сви мушки 
учесници истраживања истичу да је већина пријатеља престала да се дружи са њима и почела је редовно да их вређа користећи разне погрдне речи након сазнања да су хомосексуалне оријентације. Главни разлог избегавања геј особа од стране пријатеља је био тај што су се бојали реакције окружења, односно, нису желели да их други људи исмевају, јер се друже са геј особама. Како један учесник истраживања наводи своје искуство: „Сећам се када сам свом дотадашњем најбољем пријатељу, са којим се дружим од малена рекао да сам геј, он је прво био у шоку, а касније је почео да ме избегава и да се дистанцира од мене. После неколико дана ме је позвао и отворено рекао да је најбоље да прекине сваки контакт са мном, јер не жели да га други зезају како има геј пријатеља”. Са друге стране, учеснице истраживања истичу да су им пријатељице са којима се дуги низ година друже заправо биле највећа подршка у том периоду када су одлучиле да проговоре о својој хомосексуалности.

Овакав податак указује да се гејеви сусрећу са већим степеном неприхваћености који им отежава склапање нових социјалних контаката и очување старих контаката, односно, постоји виши степен толеранције према женској него мушкој хомосексуалности. У истраживању ставова према мушкој и женској сексуалности (Николајевић, 2012) спроведеном на студентској популацији, добијени су слични резултати. Наиме, установљено је да су испитаници толерантнији према испољавању женске него према испољавању мушке хомосексуалности.

\section{Испитивање искуства учесника истраживања приликом запослења и међуљудски односи на радном месту}

Бројни радови указују да су ЛГБТ особе дискриминисане на тржишту рада и приликом запошљавања, али не постоје јасни подаци о степену ове дискриминације најчешће због скривања, односно тога што особа може да сакрије своју сексуалну оријентацију и на тај начин избегне дискриминацију на основу родног идентитета (Милановић и Антонијевић-Приљева, 2018: 14).

Из овог разлога у наставку фокус-групног интервјуа настојало се, са једне стране, да се провери каква су искуства учесника истраживања на подручју тржишта рада, односно, да ли су приликом запослења имали потешкоћа уколико је потенцијални послодавац знао њихову сексуалну оријентацију, а са друге стране, проверити какав су однос према учесницима истраживања имали надређени и колеге на самом радном месту уколико су били упознати са њиховом сексуалношћу.

Приликом разматрања да ли су учесници истраживања имали потешкоћа приликом запослења уколико је потенцијални послодавац знао њихову сексуалну оријентацију, показало се да учесници истраживања нису током разговора за посао истицали своју сексуалност, али је она играла снажну улогу на разговору за посао у случају гејева. Наиме, већина мушких учесника истраживања је истакла да их је послодавац одбио за посао, иако су испуњавали све услове конкурса за одређену радну позицију, јер је на основу њихове гестикулације и 
начина говора наслутио њихову сексуалну оријентацију. Један учесник истраживања дели са нама своје искуство: „На разговору за посао у једној београдској фирми послодавац је рекао да испуњавам све критеријуме за позицију за коју је расписан конкурс, али да му се не свиђа начин на који говорим и облачим се, као и моји покрети руку, те да ћу им тим исфеминизираним и женскастим понашањем нанети већу штету, него корист”. Генерално, сви учесници истраживања су се макар једном сусрели са таквом или сличном ситуацијом, док учеснице истраживања нису имале проблема приликом запослења због своје сексуалне оријентације.

Када је реч о самом искуству ЛГБТ особа на радном месту, на основу разговора са учесницима истраживања, може се приметити да су се сви мушки учесници, чије су колеге знале њихову сексуалност, сусрели са негативном дискриминацијом која се испољавала у виду подсмеха и вређања од стране колега, искључиво на рачун њихове сексуалне оријентације, као и до смањивања плата од стране послодаваца окривљујући их да не обављају посао онако како треба. Такође, ниједан надређени на радном месту није стао у одбрану запослених који су гејеви, чак су поједини шефови били и иницијатори негативне дискриминације засноване на сексуалности.

Са друге стране, када је реч о учесницама истраживања ситуација је потпуно супротна. Лезбејке се нису сусреле са проблемима и потешкоћама као гејеви на радном месту због своје сексуалности, чак се у једном случају може уочити и позитивна дискриминација. Једна испитаница је истакла да је након сазнања њеног шефа да је хомосексуалне оријентације почела стално да напредује како у погледу положаја на радном месту тако и у погледу плате, док пре тог сазнања није напредовала на послу иако је дуги низ година радила у тој фирми. Међутим, како испитаница истиче, иза овог напредовања налазио се скривени мотив послодаваца: „Након што је мој послодавац сазнао да сам хомосексуалне оријентације, јер ме је једном приликом видео са партнерком у клубу, почела сам на послу стално напредовати у погледу бољег положаја и плате. У први мах ми није било јасно то изненадно напредовање, јер дуги низ година радим у тој фирми и нисам добијала унапређења. Наравно, иза свега овога је био скривени мотив послодавца, јер ми је једном приликом послао поруку како би желео да има сексуални однос заједно са мном и мојом партнерком, након чега сам одмах дала отказ у тој фирми".

Генерално, искуства особа хомосексуалне оријентације на радном месту се разликују у односу на пол. Сви мушки учесници истраживања сусрели су се са негативном дискриминацијом на радном месту од стране колега и надређених у случају да су упознати са њиховом сексуалном орјентацијом, док је код учесница истраживања уочено одсуство негативне дискриминације на послу због њихове сексуалности. У појединим случајевима је код учесница истраживања примећена и позитивна дискриминација.

Овакви подаци указују да, као и у случају социјалних контаката постоји виши степен толеранције према испољавању женске, него мушке хомосексуалности. Овај налаз је у складу са резултатима и налазима ранијих истраживања 
који указују да је људима прихватљивији, па чак и привлачнији призор сексуалног чина између две жене, него између два мушкарца који се често означава као гадан и мучан (Николајевић, 2012).

\section{Закључак}

Резултати овог истраживања у великој су мери подударни са налазима бројних истраживања која указују на постојање већег степена толеранције према лезбејкама у односу на гејеве, који се сусрећу са бројнијим проблемима како у друштвеним односима, тако и у сфери рада (Николајевић, 2012; Вуковић, 2010; Геј стрејт алијанса, 2014).

Пре свега, када је реч о испитивању реакције чланова породице на хомосексуалну оријентацију учесника истраживања, може се уочити да је у свим случајевима њу карактерисало неприхватање, неподржавање, критика, као и осуда од стране чланова породице. Са друге стране, код свих учесника истраживања укућани су након одређеног времена у мањој или већој мери прихватили хомосексуалност члана своје породице, али су односи унутар саме породице у одређеној мери захладили, односно промењени су у односу на период пре признања. Ова промена у односима и дистанца се огледа у смањеном контакту са члановима породице који нису учестали као раније, али је и присутан мањи степен поверења. Сви учесници истраживања се, без изузетка, много ређе одлучују да се о својим проблемима поверавају и посаветују са члановима своје породице него што је то раније био случај. Овим истраживањем се показало да је временска одредница битна као варијабла у процесу прихватања хомосексуалности чланова породице, будући да су код свих учесника истраживања након одређеног временског периода родитељи прихватили сексуалност члана своје породице. Из тог разлога у неком од наредних истраживања се то може поставити као једна од полазних хипотеза која би се проверила на већем узорку.

Када је реч о утицају хомосексуалности учесника истраживања на њихове социјалне контакте, можемо закључити да ЛГБТ особе немају потешкоћа приликом склапања нових пријатељстава све док је њихова сексуалност у сенци. До дисфункционалности у друштвеним односима долази када открију своју сексуалну оријентацију, при чему су гејеви у већој мери изложени бројним негативним реакцијама које се крећу од подсмеха и избегавања, преко увреда, па до физичких напада. Такође, приликом склапања нових пријатељстава присутан је различит однос према гејевима у односу на лезбејке будући да постоји виши степен толеранције према женској него мушкој хомосексуалности, што потврђује налазе претходних истраживања. Када је реч о подршци блиских пријатеља приликом признавања хомосексуалне оријентације учесника истраживања, показало се да су се мушкарци приликом откривања своје сексуалности сусрели са увредама и избегавањем од стране дугогодишњих пријатеља, док су женама пријатељи са којима се дуги низ година друже заправо били највећа подршка у том периоду. 
Резултати истраживања показују већи степен толеранције према лезбејкама него према гејевима и у самој сфери рада. Наиме, мушкарци хомосексуалне оријентације теже проналазе запослење, при чему се и на самом радном месту суочавају са разним типовима негативне дискриминације која се испољава у виду увреда од стране колега на рачун њихове сексуалности до кажњавања у виду премештања на ниже положаје и смањивања плата од стране послодаваца под изговором да не обављају посао онако како треба. Са друге стране, у случају лезбејки, негативна дискриминација на радном месту није присутна због њихове сексуалности, чак је у појединим случајевима присутна и позитивна дискриминација. Ово истраживање искустава ЛГБТ особа у међуљудским односима, као и у сфери рада потврђује резултате бројних истраживања на ову тему и указује да је и даље присутан виши степен толеранције према испољавању женске него мушке хомосексуалности.

\section{Литература}

Бојанин, С. (2014). „Хомосексуалност у средњовековној Србији”. У Ј. Благојевић и О. Димитријевић (ур.), МЕЂУ НАМА: Неиспричане приче геј и лезбејских живота (22-39). Београд: Хартефакт Фонд.

Бекер, Х. С. (1998). „Девијантност и девијанти”, прев. У И. Спасић (ур.), Интерпретативна социологија (75-86). Београд: Завод за уџбенике и наставна средства.

Вуковић, Ђ. et al. (2010). Предрасуде на видело - хомофобија у Србији 2010: Истраживање и анализа: јавног мњења, ставова ЛГБТ популаиије, дискриминације на радном месту. Beograd: CeSID i Gej strejt alijansa.

Викс, Џ. (2009). Конструкција хомосексуалности, Теме XXXIII (1), 17-46.

Геј стрејт алијанса (2014). Годишњи извештај о стању људских права ЛГБТ особа у Србији за 2014. годину, доступно на: http://gsa.org.rs/wp-content/uploads/2015/03/ GSA-izvestaj-2014.pdf (приступљено 05.2.2020.)

Дуишин, Д. и Баришић, J. (2014). „Концепт, контекст и ставови према хомосексуалности - историјски осврт”. У Ј. Благојевић и О. Димитријевић (ур.), MEЂУ НАМА: Неиспричане приче геј и лезбејских живота (104-112). Београд: Хартефакт Фонд.

Кондор-Лангер, М. (2015). Заштита права ЛГБТ особа: законодавство и полиција. Криминологија и социјална интегращија, XXIII (2), 282-305.

Милановић, М. И Антонијевић-Приљева, М. (2018). Достојанство народу: Истраживање о положају ЛГБТ особа у области рада и запошљавања. Београд: Центар за истраживање и развој друштва.

Николајевић, А. (2012). Да ли су лезбејке „мање зло: Истраживање ставова према мушкој и женској сексуалности. Годищњак за соџиологију, VIII (9), 39-58.

Сајдмен, С. (2009). Социјални конструкционизам: Социологија, историја и филозофија. Теме, XXXIII (1), 67-78. 
Стојановић, A. et al. (2016). Стигматизација младих ЛГБТ особа од стране државних институција. Ниш: Центар за социјални рад „Свети Сава”.

Спасић, И. (2000). „Хомосексуалност и социологија: Од патолошког модела до друштвеног конструкта", доступно на: http:/www.gay-serbia.com/ teorija/2000/00-02-15-sociologija/index.jsp?aid=60 (приступљено 10.02.2020.)

Чаушевић, J. et al. (2013). „Права лгбт особа у Босни и Херцеговини: здравство”, доступно на: http://www.fondacijacure.org/files/Zdravstvo\%20knjiz.blok.\%20 za\%20stampu.pdf (приступљено 03.06.2020.)

Хулић, А., Југовић, И., Каменов, Ж. (2015). Ставови студената о правима особа хомосексуалне оријентације. Ревија за социјалну политику, XXII (2), 219-244.

Ben-Ari, A.T. (1989). The process of „,coming out”: Views from parents and young gay adults (Unpublished doctoral dissertation). University of California, Berkley.

Weeks, J. (1990). Sexuality and its Discontents: Meaning Myths and Modern Sexualities. London and New York: Routledge.

\section{Mario Cekić}

\section{EXPERIENCE OF LGBT INDIVIDUALS IN INTERPERSONAL RELATIONS AND IN THE PROFESSIONAL SPHERE IN SERBIA}

Abstract: Personal experience of LGBT individuals in interpersonal relations and in the professional sphere has been defined based on the results of research obtained by focus-group interviews. The research has been conducted on the sample of 6 participants, i.e., 3 male and 3 female members of LGBT population. The paper focuses on the experience of LGTB individuals in interpersonal relations and in the professional sphere and confirms the results of extensive research which indicate that there is a much higher level of tolerance to female homosexuality than tolerance to male homosexuality. Research results emphasize that gay men are faced with more serious concerns, both in interpersonal relations and in the professional sphere than lesbians. As a rule, all research participants have experienced disapproval and condemnation from their parents after revealing their sexual orientation. Even though family members of LGBT individuals have accepted their sexuality over time, their mutual relations have inevitably changed. Participants' contacts with family members have been significantly reduced, as they do not share their feelings or confide in the members of their families as they used to. Additionally, after coming out about their sexuality, gay men have suffered insults and aversion from their friends or faced numerous difficulties when trying to make new friends. On the other hand, lesbian participants in the research have not seen their sexual orientation as an obstacle to making new friends or interacting with their old friends and acquaintances. With regard to experiences of LGBT individuals in the professional sphere, research has shown that male participants experience difficulties while trying to find an adequate 
job, as well as that they are subjected to negative discrimination at the workplace. On the other hand, female participants do not have the feeling of being discriminated due to their sexuality, but often report positive discrimination.

Keywords: homosexuality, experience of LGBT individuals, social contacts, professional sphere 